\title{
EKSEKUSI JAMINAN HAK TANGGUNGAN NASABAH WANPRESTASI AKAD MUSYARAKAH DALAM PERSPEKTIF PERLINDUNGAN KONSUMEN
}

\author{
Shofa Fathiyah $^{1}$, Nurhasanah ${ }^{2}$ \\ Fakultas Hukum Universitas Muhammadiyah Tangerang \\ E-mail:shofathiyah@gmail.com \\ nurhasanah@uinjkt.co.id
}

\begin{abstract}
Abstrak
Penelitian ini berangkat dari isu mengenai upaya penyelesaian lelang hak tanggungan dilakukan dengan adanya berbagai pilihan penyelesaian yaitu kekuasaan sendiri melalui pelelangan umum atau dilaksanakan atas perintah Ketua Pengadilan. Selain itu Debitur wanprestasi pada perbankan syariah memiliki perlindungan yang dilindungi oleh Perundang-undangan perspektif Perlindungan Konsumen. Berdasarkan hal tersebut, Peneliti mengangkat tiga rumusan masalah: Bagaimana prosedur eksekusi hak tanggungan pada perkara di Pengadilan Agama, Bagaimana Pertimbangan Hakim dalam memutus perkara Nomor 1901/Pdt.G/2016/PA.JS dan Bagaimana perlindungan nasabah terkait transparasi kecukupan jaminan, total hutang dan biaya ganti rugi dalam perspektif Perlindungan Konsumen. Metode yang digunakan merupakan metode penelitian kualitatif dan pendekatan yang digunakan adalah pendekatan sosiologi hukum. Sumber data dari penelitian ini terbagi menjadi dua kategori: sumber hukum primer yang terdiri dari Putusan Pengadilan Nomor 1901/Pdt.G/2016/PA.JS, Peraturan Perundang-undangan nomor 8 tahun 1999 tentang Perlindungan Konsumen, Peraturan OJK Nomor 1/POJK.07/2013 tentang Perlindungan Konsumen Sektor Jasa Keuangan dan Undang-undang Nomor 4 Tahun 1996 Tentang Hak Tanggungan atas Tanah Beserta Benda-benda yang Berkaitan dengan Tanah. Data sekunder: Wawancara dengan Hakim Pengadilan Agama Jakarta Selatan. Kesimpulan tesis, prosedur eksekusi Hak Tanggungan, pada perkara Nomor 1901/Pdt.G/2016/PA.JS dilakukan secara parate eksekusi, hal tersebut tidak sesuai dengan Undang-undang Nomor 4 Tahun 1996 Tentang Hak Tanggungan atas Tanah Beserta Benda-benda yang Berkaitan dengan Tanah Penjelasan Umum Angka 9 dan Buku Standar Operasional Musyarakah OJK, "BUS/UUS/BPRSuntuk tercapainya kepastian hukum dan Perlindungan nasabah terkait transparasi kecukupan jaminan, total hutang dan biaya ganti rugi dengan prinsip transparansi diatur Pasal 2 Peraturan Otoritas Jasa Keuangan Nomor: 1/POJK.07/2013 tentang Perlindungan Konsumen Sektor Jasa Keuangan.
\end{abstract}

Kata kunci: Perlindungan Hukum, Teori Tujuan Hukum, Eksekusi Jaminan, Pengadilan Agama, Nasabah Akad Musyarakah, Bank Syariah. 


\title{
EXECUTION OF ENCUMBRANCE RIGHT \\ THE DEBTOR'S DEFAULT OF MUSYARAKAH AGREEMENT IN THE PERSPECTIVE OF CUNSUMER PROTECTION LAW
}

\begin{abstract}
This research departs from settling issues regarding the execution of encumbrance right with a variety of options, may sell by virtue of his own authority the Encumbrance right object in a public auction or executed orders of the head of district court. In addition the debtor breach of contract on Islamic banking have protection that is protected by a statutory consumer protection perspective. Based on the foregoing, the researcher raised three issues: How is the procedure execution of encumbrance right in the Religious Court, how to disconnect a judge in consideration of case numbers 1901/Pdt. G/2016/PA. JS and how complete the adequacy customer protection guarantee, total debt and the cost of compensation in the perspective of consumer protection. The method used is a qualitative research methods and approaches sociological approach used was legal. The data source of this research is divided into two categories: primary legalsources which consist of perpetual numbers 1901/Pdt. G/2016/PA.JS, Legislation number 8 year 1999 on the protection of consumers, the regulation OJK the number 1/POJK. 07/2013 about consumer protection in the financial services sector Law of The Republic of Indonesia Number 4 of 1996 regarding encumbrance right over land and land-related objects. Secondary data: interview with the religious court judge south Jakarta. The conclusion of the thesis, the procedure of execution of encumbrance right on the matter of numbers 1901/Pdt. G/2016/PA. JS carried out the execution, it is parate not in accordance with Law of The Republic of Indonesia Number 4 of 1996 regarding encumbrance right over land and land-related objects of general stipulations article 9 and operational standards Musyarakah OJK, BUS/"UUS/BPRS to achieve the legal certainty protection pf related clients complete sufficiency guarantee, total debt and compensation costs under the transparency principle are regulated in article 2 of the financial services authority regulation number :1/POJK.07/2013 conceming financial sector consumer protection.
\end{abstract}

Keywords: Legal Protection, Legal Purpose Theory, Execution of Guarantees, Religious Courts, Musyarakah Agreement, Islamic Banks. 


\section{PENDAHULUAN}

Pada pelaksanaan eksekusi hak tanggungan merupakan suatu kesatuan yang tidak terpisah dari pelaksanaan tata tertib beracara yang terkandung dalam HIR atau RBG. ${ }^{1}$ Pelaksanaan penjualan objek hak tanggungan melalui pelelangan diatur dalam Pasal 6 Undang-Undang Nomor 4 Tahun 1996 Tentang Hak Tanggungan atas Tanah Beserta Benda-benda yang Berkaitan dengan Tanah. ${ }^{2}$ Sertifikat hak tanggungan pada Pasal 14 mempunyai kekuatan eksekutorial yang sama dengan putusan Pengadilan maka Pemegang Hak Tanggungan cukup mengajukan permohonan kepada Kepala Kantor Pelelangan Umum (KKPU).

Kendala yang dihadapi adalah apabila objek lelang jaminan Hak Tanggungan dilakukan langsung Kantor Pelelangan Umum terdapat perlawanan dari debitur atau pihak lain maka KPKNL tidak memiliki kewenangan untuk melakukan eksekusi. Pelaksanaan lelang pada Pasal 6 tanpa fiat eksekusi Pengadilan secara teoritis pasal tersebut terkendala dengan Pasal 26 dilihat dari sertifikat Hak Tanggungan yang berlaku sebagai pengganti grosse acte hypotheek, pelaksanaan eksekusinya memperhatikan pula ketentuan hukum acara perdata. Pengadilan menganggap bahwa objek lelang yang dijual oleh KPKNL tidak terdapat peletakkan sita (beslag) oleh badan Pengadilan. Sementara prosedur hukum untuk melakukan eksekusi pengosongan mewajibkan harus adanya penetapan sita oleh Pengadilan, dasar dilakukan eksekusi pengosongan (Pasal 200 ayat (11) HIR/ Pasal 218 ayat (2) RBg). ${ }^{3}$

Pelaksanaan eksekusi hak tanggungan pembiayaan bank syariah pada Pengadilan Agama dalam diskusi yang dikemukakan oleh Bapak Yasardin

${ }^{1}$ M. Yahya Harahap, Ruang Lingkup Permasalahan Eksekusi Bidang Perdata, (Jakarta: Sinar Grafika, 2005), hlm.1.

2 Yordan Demesky, Tesis: PelaksanaanParate Eksekusi Hak Tanggungan sebagai Alternatif Penyelesaian Kredit Bermasalah di PT Bank Permata Tbk, (Jakarta: Universitas Indonesia, 2011), hlm.87.

${ }^{3}$ Abd. Salam, Eksekusi Hak Tanggungan dalam Akad Murabahah atas Alasan Wanprestasi (Perspektif Perlindungan Nasabah),https://badilag.mahkamahagung.go.id/artikel/publikasi/artikel/eksekusi-hak-tanggungandalam-akad-murabahah-atas-alasan-wanprestasi-oleh-drs-h-abd-salam-s-h-m-h-11-9, pada tanggal 16 Oktober 2018. 
memaparkan terdapat permasalahan eksekusi di Pengadilan Agama disebabkan karena amar putusan yang tidak jelas dan tuntas. Hal ini bisa terjadi karena pemeriksaannya tidak dilengkapi dengan pemeriksaan setempat (deescente) atau karena amar itu tidak dilengkapi dengan penegasan apabila tidak bisa dibagi secara natural, maka objek sengketa akan dijual lelang dan hasilnya dibagi sesuai bagiannya masing-masing. ${ }^{4}$

Peraturan Otoritas Jasa Keuangan Nomor: 1/POJK.07/2013 tentang Perlindungan Konsumen Sektor Jasa Keuangan pasal 10 ayat 1, Seharusnya transparansi dalam pembebanan biaya lelang yang jelas disebutkan maupun biayabiaya lainnya, hakim berpendapat pada prinsipnya bahwa yang membayar lelang adalah pemohon lelang dan yang membayar gugatan sita jaminan adalah pemohon sita jaminan. ${ }^{5}$

Pihak bank yang melelang tanah yang menurut apparsial atau taksiran harga jual jaminan seharusnya lebih besar dari total pinjaman sebagai mitigasi resiko perbakan dalam mencairkan pembiayaan namun bank yang melelang tanah dibawah jumlah total hutang yang tentu berakibat adanya ketidakadilan yang dirasakan bagi pihak nasabah yang seharusnya nasabah mendapatkan transparansi jumlah penilaian jaminan sesuai aturan berdasarkan pada prinsip transparasi berdasarkan pasal 2 Peraturan Otoritas Jasa Keuangan Nomor: 1/POJK.07/2013 tentang Perlindungan Konsumen Sektor Jasa Keuangan.

\section{METODE PENELITIAN}

Bentuk penelitian ini termasuk dalam kategori penelitian kajian Penelititan Kepustakaan (library research) berupa Regulasi OJK, peraturan perundangundangan, fatwa DSN-MUI, dan pendekatan kasus. Hal pokok yang dikaji adalah pertimbangan hakim untuk sampai pada suatu keputusan sehingga

\footnotetext{
${ }^{4}$ https://badilag.mahkamahagung.go.id/seputar-ditjen-badilag/seputar-ditjen-badilag/sitadan-eksekusi-hak-tanggungan-syari-ah-dibedah-dalam-diskusi-hukum-korwil-i-pta-bandung-8-12, diakses pada tanggal 6 Desember 2017.

5 Wawancara dengan Cece Rukmana Ibrahim Tanggal 9 Oktober 2018 di Pengadilan Agama Jakarta Selatan
} 
dapat digunakan sebagai argumentasi dalam memecahkan isu hukum yang dihadapi. ${ }^{6}$ Dalam pencarian jawaban permasalahan yang dikemukakan maka jenis penelitian dalam tesis ini adalah penelitian kualitatif.

Data yang digunakan dalam penelitian ini adalah data sekunder, data sekunder yaitu data yang diperoleh dari bahan pustaka dan data primer merupakan bahan hukum primer merupakan bahan hukum yang mempunyai otoritas paling utama. ${ }^{7}$ Data primer adalah bahan-bahan hukum yang mengikat, dari sudut peraturan perundang-undangan, putusan pengadilan, yurisprudensi, perjanjian para pihak dan data sekunder merupakan bahan hukum sekunder adalah bahan hukum yang menguatkan bahan hukum primer dan dapat dipergunakan dengan memperjelas konsep dalam penelitian dengan melakukan wawancara. ${ }^{8}$ Bahan hukum sekunder berupa buku-buku teks, jurnal, tesis, hasil penelitian terdahulu mengenai masalah yang dibahas, serta literatur lainnya terkait topik pembahasan. Metode pengumpulan data dalam Penelitian ini Studi kepustakaan dan Wawancara.

Studi kepustakaan dilakukan dengan cara mempelajari dan mendalami bahan hukum primer dan sekunder serta menginventariskan data-data tersebut. Inventarisasi dengan menggunakan perundang-undangan terkait perlindungan hukum dalam sengketa ekonomi syariah dalam Peraturan Otoritas Jasa Keuangan dan undang-undang perlindungan konsumen yang menjadi objek penelitian, yang di dalam ketentuannya di lihat dari sudut pandang pendekatan normatif serta terdapat masalah hukum akad musyarakah pada putusan pengadilan agama dan Hasil wawancara terhadap narasumber yang berkompeten dengan topik penelitian ini dilakukan secara mendalam atau in-depth. Pihak yang menjadi narasumber adalah hakim Pengadilan Agama Jakarta Selatan.

Data yang berhasil diperoleh dianalisis dengan cara mengkaitkan aturan pelaksanaan eksekusi hak tanggungan yang diatur dalam Undang-Undang Nomor

${ }^{6}$ Peter Mahmud Marzuki, Penelitian Hukum, (Jakarta: Kencana Prenada Media Group, 2011), hlm. 138.

${ }^{7}$ Peter Mahmud Marzuki, Penelitian Hukum, hlm. 181.

${ }^{8}$ Soejono Soekanto dan Sri Pamudji,Penelitian Hukum Normatif,hlm. 12. 
4 Tahun 1996 Tentang Hak Tanggungan apakah sudah sesuai prosedur dan sengketa ekonomi syariah di pengadilan agama memberikan perlindungan hukum. Peneliti akan menganalisis putusan pengadilan sengketa ekonomi syariah memberikan kepastian hukum pada amar putusan dalam transparansi jumlah lelang hak tanggungan dan ganti kerugian akibat debitur wanprestasi sesuai fatwa DSN-MUI. Analisis juga dikaitkan dengan hasil wawancara yang diperoleh dengan teori-teori hukum yang dipakai dalam penelitian.

Teori Tujuan Hukum menurut Gustav Radbruch

Gustav Radbruch mengungkapkan teori hukum dalam keberadaannyamemiliki tujuan yaitu hukum dibuat untuk mencapai keadilan, kepastian hukum dan kemanfaatan ${ }^{9}$ (Gerechtigkeit Rechts sicherheit und Zweckmachtigkeit). ${ }^{10}$ Ketiga aspek tersebut menjadi rujukan utama baik dalam pembuatan peraturan perundang-undangan maupun proses penegakan hukum dalam masyarakat. ${ }^{11}$ Aspek keadilan dilihat kepada kesamaan hak dimata hukum yang bertujuan memajukan kebaikan dalam kehidupan manusia dan menentukan isi hukum. Kepastian hukum berfungsi sebagai peraturan yang harus ditaati ${ }^{12}$ dan dalam penegakan hukum harus memberi manfaat atau kegunaan.

Keadilan dalam Hukum Ekonomi Syariah

Konsep keadilan dalam hukum islam yaitu menempatkan sesuatu hanya pada tempatnya dan memberikan sesuatu hanya pada yang berhak serta memperlakukan sesuatu sesuai posisinya. Keadilan sebagai tribuere jus suum cuique artinya memberi masing-masing haknya. ${ }^{13}$ Islam dalam menegakan tujuannya yaitu menghapuskan segala bentuk kedzaliman semua bentuk ketidakadilan sehingga seseorang menjauhkan hak orang lain atau tidak

9 Achmad Ali, Menguak Teori Hukum (Legal Theory)\&Teori Peradilan (Judicial prudence) Termasuk Undang-Undang (Legisprudence), vol. I, (Jakarta: Kencana Prenada Media Group, 2010), hlm. 288.

${ }^{10}$ Gustav Radhbruch, Rechtsphilosophie, (Stuttgart: K.F Koehler Verlag, 1973), hlm. 142.

${ }^{11}$ Supianto, Hukum Jaminan Fidusia, Prinsip Publisitas Pada Jaminan Fidusia, (Garudhawaca, 2015), hlm. 85.

${ }^{12}$ Abdul Salam Siku, Perlindungan Hak Asasi Saksi dan Korban dalam Proses Peradilan Pidana, (Indonesia Prime, 2016), hlm. 9.

${ }^{13}$ Kirdi Dipoyudo, Keadilan Sosial, (Jakarta: Rajawali Pers, 1985), hlm. 23, Lihat,Eva Zulfa Nailufar, Disertasi:Studi Kritis UMP DKI dalam Perspektif Sistem Pengupahan Berkeadilan Menurut Islam, (Jakarta: UIN Syarif Hidayatullah, 2014), hlm. 48. 
memenuhi kewajiban. ${ }^{14}$

M. Umer Chapra mengungkapkan keadilan bidang ekonomi terbagi dalam empat hal: need fulfilment (pemenuhan kebutuhan), respectable source of earning (sumber penghasilan yang terhormat), equitable distribution of income and wealth (distribusi penghasilan dan harta yang berkeadilan) dan growth and stability (perkembangan dan stabilitas). ${ }^{15}$ Oleh karena itu dengan ditegakannya keadilan maka manusia akan dapat menikmati perkembangan dan stabilitas ekonomi. ${ }^{16}$

Amirul Mukminin Umar bin Khattab melakukan langkah dalam mencapai kesejahteraan sosial di bidang ekonomi, dengan adanya keadilan sosial dan sumber dana yang jelas dari para khalifah (pemerintah) dengan mengambil sumber dana baitul mal akan dibagikan kepada masyarakat dalam pembiayaan negara demi kesejahteraan masyarakat. ${ }^{17}$ Umar bin Khattab melakukan prinsip ekonomi yang dapat menjamin keadilan, baik motivasi individu, bisnis maupun kenegaraan. ${ }^{18}$

\section{PEMBAHASAN}

Prosedur eksekusi hak tanggungan akad musyarakah pada perkara di Pengadilan Agama.

Pelaksanaan eksekusitorial diatur dalam Pedoman Pelaksanaan Tugas dan Administrasi Peradilan Agama Buku II: "Sertifikat hak tanggungan mempunyai kekuatan eksekusitorial yang sama dengan putusan pengadilan yang telah mempunyai kekuatan hukum tetap dan jika tergugat cidera janji maka berdasarkan titel eksekusitorial yang terdapat dalam sertifikat hak tanggungan tersebut. Namun hal tersebut tidak secara otomatis dalam pelaksanaan eksekusi hak tanggungan

\footnotetext{
${ }^{14} \mathrm{M}$. Umer Capra, Islam and the economic Challege,(Leicester: The Islamic Foundation, 1994), terj. Ikhwan Abidin Basri, Islam dan Tantangan Ekonomi, (Depok: Gema Insani: 2000), hlm. 211.

15 M. Umer Chapra, Islam and the Economic Challenge, (Leicester: The Islamic Foundation, 1994), p. 210-213. hlm. 31 .

${ }^{16}$ Idri, Hadis Ekonomi,Ekonomi dalam Perspektif Hadis Nabi, (Jakarta: Kencana, 2015),

17 Sulaeman Jajuli, Ekonomi Islam Umar bin Khattab, (Yogyakarta: Deepublish, 2016), hlm. 11 .

${ }^{18}$ Sulaeman Jajuli, Ekonomi Islam Umar bin Khattab, hlm. 224.
} 
dapat langsung dilaksanakan dengan eksekusi rill.

Sebelum pelaksanaan lelang diperlukan peletakan sita eksekusi, dikarenakan salah satu ketentuan dalam eksekusi lelang terlebih dahulu ada ketentuan untuk dilaksanakan sita eksekusi. ${ }^{19}$ Prosedur yang sesuai adalah pemegang hak tanggungan memohon eksekusi Sertifikat Hak Tanggungan kepada ketua Pengadilan Agama/Mahkamah Syariah yang berwenang. Selanjutnya eksekusi akan dilakukan seperti eksekusi putusan yang telah berkekuatan hukum tetap. Sesuai denganUndang-undang Nomor 4 Tahun 1996 Tentang Hak Tanggungan atas Tanah Beserta Benda-benda yang Berkaitan dengan Tanah dilihat pada Penjelasan Umum Angka 9 bahwa parate eksekusi Hak Tanggungan dilakukan berdasarkan Pasal 224 HIR/258 Rbg maka eksekusi tersebut tetap harus berdasarkan penetapan dari Ketua Pengadilan Negeri setempat (fiat Pengadilan).

Berdasarkan hasil wawancara hakim pengadilan agama Jakarta mengungkapkan Prosedur eksekusi idealnya berperkara dahulu setelah nasabah diputus telah wanprestasi dan dihukum untuk membayar jumlah kewajibannya maka dapat dilakukan eksekusi lelang jaminan. Dengan demikian pihak bank mengajukan permohonan eksekusi terlebih dahulu kepada Pengadilan Agama dan selanjutnya Pengadilan Agama menindak lanjutinya selayaknya eksekusi putusan yang telah berkekuatan hukum tetap. ${ }^{20}$

Jaminan kebendaan dalam bentuk Hak Tanggungan yang berupa Akta Pemberian Hak Tanggungan dalam pembiayaan musyarakah pada perbankan syariah belum sesuai dengan hukum Islam dikarenakan terdapat beberapa kewenangan di dalam akta Hak Tanggungan tersebut belum sesuai dengan

19 Al Fitri, Perlukah Sita Eksekusi Terhadap Objek Hak Tanggungan, Hakim Madya Pratama Pengadilan Agama Blamabangan Umpu. https://badilag.mahkamahagung.go.id/artikel/publikasi/artikel/perlukah-sita-eksekusi-terhadapobjek-hak-tanggungan-oleh-al-fitri-s-ag-s-h-m-h-i-19-7, diakses pada tanggal 16 Oktober 2018

${ }^{20}$ Zuhrul Anam, Prosedur Eksekusi Putusan Basyarnas, Hak Tanggungan dan Putusan Pengadilan Agama yang Simetris, https://badilag.mahkamahagung.go.id/artikel/publikasi/artikel/prosedur-eksekusi-putusanbasyarnas-hak-tanggungan-dan-putusan-pengadilan-agama-yang-simetris-oleh-m-yeri-hidayat-s-hdan-zuhrul-anam-s-h-i-27-8 diakses pada tanggal 16 Oktober 2018 
ketentuan hukum Islam. ${ }^{21}$ Hal ini dikarenakan dalam pembiayaan di keuangan syariah tidak seluruhnya berbasis utang piutang, namun juga ada yang berbasis modal kerja dan jasa. Pada model pembiayaan akad musharakah adalah kesepakatan antara dua pihak dalam hal pokok modal dan keuntungan. Keuntungan yang dibagi berdasarkan porsi modal, ${ }^{22}$ Maka musyarakah tidak ditemukan adanya utang-piutang secara prinsip sehingga penerapan jaminan fidusia tidak kompatibel dengan model pembiayaan tersebut. Jaminan surat ( $a l$ rahn al-tasjili) adalah bentuk jaminan yang dikenalkan dalam Islam atau dalam perkara ini jaminan kebendaan hak tanggungan yang memiliki kemiripan dengan jaminan fidusia meskipun tidak sama persis. ${ }^{23}$ Namun Standar Produk Perbankan Syariah Musyarakah dan Musyarakah Mutanaqishah bahwa BUS/UUS/BPRS boleh meminta kepada Nasabah agar memberikan kuasa kepada BUS/UUS/BPRS untuk pembebanan Hak Tanggungan, Hak Gadai atau Hak Jaminan.

Pada perkara pihak perbankan telah melaksanakan pelelangan Jaminan Hak Tanggungan diluar pengadilan dengan parate eksekusi sebelum permohonan dan perkara wanprestasi masuk ke Pengadilan Agama hal tersebut dikaitkan dengan Standar Produk Perbankan Syariah Musyarakah dan Musyarakah Mutanaqishah Otoritas Jasa Keuangan bahwa Pihak BUS/UUS/BPRS tidak diperkenankan melakukan eksekusi agunan dan jaminan secara langsung sesaat setelah terjadi tunggakan ataupun wanprestasi sebelum ada putusan pengadilan yang menyatakan bahwa Nasabah lalai dan memberikan hak kepada BUS/UUS/BPRS untuk eksekusi agunan dan jaminan. ${ }^{24}$ Lemahnya posisi hukum bank syariah tidak dapat menggunakan surat pengakuan hutang, maupun meletakan hak tanggungan (APHT) atas pengalihan kepemilikan. ${ }^{25}$

\footnotetext{
${ }^{21}$ Abdul Munir, Akta Pemberian Hak Tanggungan dalam Pembiayaan Musyarakah pada Perbankan Syariah Menurut Hukum Islam, (Tesis, Universitas Sebelas Maret, 2015), hlm, iii.

${ }^{22}$ Muhammad Maksum, Penerapan Hukum Jaminan Fidusia Dalam Kontrak Pembiayaan Syariah, (Jurnal Cita Hukum, FSH UIN Syarif Hidayatullah Jakarta Vol.3 No.1, 2015), hlm. 7.

${ }^{23}$ Muhammad Maksum, Penerapan Hukum Jaminan Fidusia Dalam Kontrak Pembiayaan Syariahlm.hlm. 1. 53.

${ }^{24}$ Standar Produk Perbankan Syariah Musyarakah dan Musyarakah Mutanaqishah, hlm.

${ }^{25}$ Standar Produk Perbankan Syariah Musyarakah dan Musyarakah Mutanaqishah, hlm. 5.
} 
Asas kepastian hukum (pacta sunt servanda) yaitu para pihak berkeyakinan bahwa apa yang sudah dijanjian dalam perjanjian dijamin dalam pelaksanaannya sesuai dengan teori kepastian hukum yang diungkapkan oleh Peter Mahmud Marzuki bahwa kepastian hukum tersebut membuat individu mengetahui perbuatan apa yang boleh atau tidak dilakukan maka kepastian hukum dalam hal eksekusi jaminan bahwa kekuatan eksekusitorial/kekuatan untuk dilaksanakan putusan hakim yang sudah berkekuatan hukum tetap terhadap pihak yang dikatakan kalah dalam perkara dan dilakukan secara sukarela, apabila terhadap pihak yang tidak menaatinya secara sukarela maka kekuatan ini dinamakan kekuatan eksekusitorial maka pengadilan memiliki kewenangan untuk melakukan eksekusi secara paksa. ${ }^{26}$

Analisis penulis bahwa sebelum melakukan lelang jaminan idealnya harus ada penetapan sita jaminan kepada majelis hakim dilanjutkan permohonan eksekusi sita jaminan ke ketua pengadilan agama hal ini disebabkan Rahn tidak terjadi peralihan kepemilikan objek jaminan tersebut selama utang belum dilunasi, objek jaminan baru dapat dieksekusi ketika nasabah benar-benar tidak mampu membayar. ${ }^{27}$ Hasil penjualan lelang jaminan yang sudah terjual badan lelang jika ada kelebihannya, pengadilan menjadi pihak perantara untuk pengembalian kepada Tergugat, jika pihak bank langsung mengembalikan sisa penjualan tersebut harus dihadapan pengadilan. Sisa penjualan lelang dititipkan di pengadilan agama disebut uang konsinyasi yang menjadi tanggung jawab panitera pengadilan agama apabila hal tersebut dilaksanakan dalam pelaksanaan eksekusi hak tanggungan sesuai teori kepastian hukum oleh Peter Mahmud Marzukibahwa kepastian hukum merupakan konsistensi dalam putusan hakim untuk kasus serupa yang telah diputus.

Permohonan eksekusi hak tanggungan atau eksekusi sita jaminan kepada ketua pengadilan agama yang harus memutus, dalam gugatan wanprestasi maka ketua pegadilan menunjuk majelis hakim untuk menangani gugatan wanprestasi.

${ }^{26}$ R. Soebekti, Hukum Acara Perdata), (Bandung: Bina Cipta, 1989), hlm.128 lihat Sunarto, Peran Hakim dalam Perkara Perdata,hlm.212.

${ }^{27}$ Muhammad Maksum, Penerapan Hukum Jaminan Fidusia Dalam Kontrak Pembiayaan Syariahlm.hlm. 9 . 
Dengan adanya Putusan Pengadilan Agama Nomor 1901/Pdt.G/2016/PA.JS yang berkekuatan hukum tetap maka pengajuan eksekusi sita jaminan ditunjukan kepada ketua pengadilan dengan melakukan ammaning dan penetapan eksekusi dan pelaksanaanya dapat langsung dilakukan oleh panitera/juru sita pengadilan agama, yang maju ke kantor lelang adalah pengadilan namun yang melakukan penjualan sita jaminan adalah kantor lelang negara. ${ }^{28}$

Eksekusi jaminan Hak Tanggungan nasabah wanprestasi Akad Musyarakah dalam Prespektif perlindungan Konsumen.

Pelaksaan eksekusitorial juga diatur dalam Pedoman Pelaksanaan Tugas Dan Administrasi Peradilan Agama Buku II: "Sertifikat hak tanggungan mempunyai kekuatan eksekutorial yang sama dengan putusan pengadilan yang telah mempunyai kekuatan hukum tetap dan jika Tergugat cidera janji maka berdasarkan titel eksekutorial yang terdapat dalam sertifikat hak tanggungan tersebut. Namun hal tersebut tidak secara otomatis dalam pelaksanaan eksekusi hak tanggungan dapat langsung dilaksanakan dengan eksekusi rill. Hakim bersikap pasif untuk menetapkan bahwa sah atau tidak sesuai atau tidak prosedur lelang hak tanggungan diluar pengadilan Perkara ini setelah melakukan penjulan lelang hak tanggungan gugatan wanprestasi baru masuk ke pengadilan maka hakim hanya menangani perkara yang ada dalam gugatan saja yaitu wanprestasi dan penetapan sita jaminan untuk pelunasan sisa kewajiban Tergugat namun jika ada yang menggugat hal tersebut maka Hakim bersifat aktif jika ada perkara masuk ke pengadilan dalam melihat kembali apakah ada prosedur yang tidak sesuai. $^{29}$

Penjualan lelang hak tanggungan terdapat pada Perlindungan nasabah berdasarkan asas-asas undang-undang nomor 8 tahun 1999 tentang perlindungan konsumen bahwa nasabah berhak menerima selisih harga penjualan jaminan setelah dikurang total hutang namun pada perkara ini jaminan hak tanggungan masih tidak memenuhi jumlah hutang maka dilakukan penjualan sita jaminan,

${ }^{28}$ Wawancara dengan Cece Rukmana Ibrahim Tanggal 9 Oktober 2018 di Pengadilan Agama Jakarta Selatan

29 Wawancara dengan Jarkasih Tanggal 10 Oktober 2018 di Pengadilan Agama Jakarta Selatan 
penjualan jaminan hak tanggungan yang menggunakan parate eksekusi yang masih belum menutupi jumlah hutang, hal tersebut menjadi permasalahan kedua belah pihak.

Pada Perkara Nomor 1901/Pdt.G/2016/PA.JS pihak bank mengajukan gugatan untuk penetapan sita jaminan yang seharusnya hakim dengan exofficionya melihat kembali dalam hal kecukupan jaminan hak tanggungan maupun sita jaminan. Disini terlihat adanya ketidakpastian dalam transparansi penilaian jaminan yang belum mencukupi jumlah hutang, seharusnya tergugat mendapatkan kepastian hukum dalam transparansi penilaian jaminan sita jaminan, apakah sudah mencukupi total kewajiban tergugat Pasal 4 Undang-Undang Nomor 8 Tahun 1999 Tentang Perlindungan konsumen hak atas informasi yang benar, jelas, dan jujur.

Kekuatan yang mengikat, pembuktian serta eksekutorial inilah yang diharapkan untuk sebuat putusan dapat memiliki perlindungan hukum terkait Eksekusi jaminan Hak Tanggungan nasabah wanprestasi Akad Musyarakah terkait nilai-nilai keadilan, Kemanfaatan atau kegunaan dan kepastian hukum bagi penegakan hukum para pihak yang bersengketa. ${ }^{30}$ Keharusan bank mengajukan permohonan eksekusi sita jaminan ini maka bank tidak dapat melakukan lelang sendiri namun harus dengan permohonan eksekusi ke pengadilan.

Perlindungan nasabah terkait biaya ganti rugi, transparasi kecukupan jaminan, total hutang dalam perspektif Perlindungan Konsumen.

Tujuan dari mengajukan gugatan ke pengadilan untuk mendapatkan putusan yang seadil-adilnya maka menurut penulis berpendapat seharusnya tergugat mempertahankan hak-haknya di hadapan hukum dengan melakukan upaya hukum agar asas-asas dalam perlindunganhukumdalam undang-undang Nomor 8 Tahun 1999 TentangPerlindungan Konsumen, yang berasaskan manfaat, keadilan, keseimbangan, keamanan dan keselamatan serta kepastian hukum dapat terwujud, maka hakim akan melihat kembali terhadap akad dan prosedur dengan secara aktif dalam memutus perkara ekonomi syariah.

\footnotetext{
${ }^{30}$ Sunarto, Peran Hakim dalam Perkara Perdata, 226
} 
Hakim dalam memeriksa gugatan wanprestasi mengutamakan gugatan yang masuk ke pengadilan kemudian melihat akad apa yang digunakan maka dicari permasalahanya yaitu wanprestasi, penetapan wanprestasi dilihat dari pembayaran yang macet maka tergugat yang melakukan keahlian dihukum dan diamarkan dalam putusan untuk membayar sisa hutang dan biaya kerugian yang disebabkan kelalainnya. ${ }^{31}$

Perlindungan terkait membayar kerugian terdapat dalam Perma sudah melindungi hak tergugat, maka dalam pertimbangan hakim boleh saja tergugat dibebankan biaya kerugian jika dianggap merugikan pihak tergugat (nasabah) seperti membayar biaya yang timbul disebabkan nasabah wanprestasi. Putusan Peninjauan Kembali Mahkamah Agung Nomor: 650 PK/Pdt/1994 tanggal 29 Oktober 1994 dengan Pertimbangan Hukum: Tuntutan ganti rugi dalam perkara perdata barulah dapat dikabulkan bila si penuntut dapat membuktikan dalam persidangan, tentang perincian adanya kerugian tersebut. ${ }^{32}$ Pada penyelesaian perkara Ekonomi Syariah dapat ditemui pada fatwa-fatwa Desan Syariah Nasional (DSN) sebagai dasar terbitnya Peraturan Bank Indonesia (PBI) atau Peraturan Otoritas Jasa Keuangan (POJK) yang cenderung menggunakan teori maslahah dan maslahah mursalah dalam upaya mendatangkan kemanfaatan bagi manusia dan menolak kerusakan (mafsadat). ${ }^{33}$ Tergugat yang tidak mampu membuktikan adanya keadaan memaksa (force majeur) maka kepadanya tidak dibebaskan dari kewajiban membayar utang untuk memberikan kepastian hukum berdasarkan teori yang diungkapkan oleh Theo Huijbers bahwa kepastian hukum diterapkan dalam kasus ini demimenjaga keamanan dan menghindari Tergugat mengulangi perbuatan yang serupa maka tergugat yang melakukan tindakan wanprestasi diwajibkan untuk membayar kerugian akibat tindakannya.

Hakim Pengadilan Agama Jakarta Selatan mengungkapkan bahwa pembebanan biaya perkara non kebendaan dibebankan ke tergugat misalnya

\footnotetext{
${ }^{31}$ Wawancara dengan Cece Rukmana Ibrahim Tanggal 9 Oktober 2018 di Pengadilan Agama Jakarta Selatan

${ }^{32}$ Sunarto, Peran Aktif Hakim dalam Perkara Perdata, hlm.38 84.

${ }^{33}$ Amran Suadi, Penyelesaian Sengketa Ekonomi Syariah, (Jakarta: Kencana, 2018), hlm.
} 
dalam gugatan perceraian. Pasal 181 ayat 1 HIR mengatur yang dibebakan biaya adalah pihak yang dikalahkan, jika kedua pihak mendapat bagian harta misalnya perkara kewarisan maka biaya tersebut ditanggung renteng, Perkara ekonomi syariah tidak harus merujuk kepada aturan dasar perkara kebendaan yaitu yang menanggung beban adalah pihak yang dikalahkan Pasal 181 ayat 1 HIR dikarenakan pertimbangan hakim dalam putusan ini bahwa ditanggung kepada pihak yang berkepentingan. ${ }^{34}$

Analisis Penulis terhadap perlindungan konsumen terkait transparansi kecukupan jaminan hak tanggungan, Majelis Hakim seharusnya memperhatikan ternyata hutang yang dipinjamkan jauh lebih besar dari hasil penjualan lelang jaminan hak tanggungan. Transaksi akad harus jelas baik harga maupun barangnya yang terbentuk dari penerapan nilai ekonomi syariah melalui perbankan dalam sektor keuangan. Jahaya S Pradja mengungkapkan perbankan syariah dalam bentuk institusionalyang diharapkan mampu melakukan pemberdayaan ekonomi bagi masyarakat. ${ }^{35}$

Pihak bank yang melelang tanah yang menurut apparsial atau taksiran harga jual jaminan seharusnya lebih besar dari total pinjaman sebagai mitigasi resiko perbakan dalam mencairkan pembiayaan, pihak nasabah yang seharusnya mendapatkan transparansi jumlah penilaian jaminan sesuai aturanberdasarkan pada prinsip transparansi berdasarkan pasal 2 Peraturan Otoritas Jasa Keuangan Nomor: 1/POJK.07/2013 Tentang Perlindungan Konsumen Sektor Jasa

Menurut Pasal 178 ayat 1 HIR menyatakan bahwa hakim secara ex officio, wajib mencakupkan segala alasan hukum yang tidak dikemukakan para pihak yang berperkara. ${ }^{36}$ Menurut penulis dari hasil wawancara seharusnya panitera atau juru sita melihat di lapangan terhadap jaminan hak tanggungan tersebut yang penjualannya jauh dibawah total hutang namun karena gugatan masuk setelah penjualan hak tanggungan hakim tidak kembali melihat hal tersebut dikarenakan

${ }^{34}$ Wawancara dengan Cece Rukmana Ibrahim Tanggal 9 Oktober 2018 di Pengadilan Agama Jakarta Selatan.

${ }^{35}$ Juhaya S. Pradja, Ekonomi Syariah, (Bandung: Pustaka Setia, 2012), hlm. 175.

${ }^{36}$ Sunarto, Peran Hakim dalam Perkara Perdata, hlm.202. 
prosedur gugatan sudah sesuai prosedur dan putusan sudah sesuai dengan hukum acara dan kompilasi hukum ekonomi syariah.

Dilihat pada Dalil mengenai diperbolehkannya pengenaan ganti rugi (alta'widh) adalah QS. Al-Baqarah tentang larangan berlaku zalim (al-zhulm) dan hadist Nabi Saw. Tentang larangan berlaku dharar dan dhirar. ${ }^{37}$ Oleh karena itu termasuk akl al-mal bi al-bathil jika Lembaga Keuangan Syariah mengenakan ganti rugi melebihi jumlah dana yang dikeluarkannya, dikhawatirkan kelebihannya dapat dikelompokan sebagai riba ( riba qardh/riba fadhl).

Perlindungan tergugat terkait total hutang dan biaya ganti rugi dari berbagai literatur bahwa metode penemuan hukum adalah melalui ultra petita atau ex officio sebab ultra petita merupakan asas hakim tidak boleh mengabulkan lebih dari yang dituntut. Namun ex aepuo et bono maksudnya permohonan kepada hakim untuk menjatuhkan putusan dengan seadil-adilnya, maka hakim dapat memutus lain dari pokok sengketa tetapi masih berkaitan dengan gugatan pada pokok sengketa seperti dalam tuntutan bunga utang yang harus dibayar, dimana hakim berpendapat besarnya bunga tersebut tidak sesuai dengan akad yang digunakan, maka hakim dapat menentukan besarnya total kewajiban dan biaya bagi hasil agar tercapainya kemanfaatan sesuai yang diungkapkan Bentham, bahwa hukum dapat memberikan jaminan kebahagiaan kepada individu secara langsung.

Putusan Mahkamah Agung Nomor: 556 K/Sip/1971 tanggal 8 Januari 1972 yang salah satu konsiderannya mengatakan: "Mengabulkan melebihi dari apa yang digugat adalah diiizinkan, selama hal ini masih sesuai dengan kejadian materil". ${ }^{38}$ Analisis penulis seharusnya hakim dalam memutus putusandalam menegakan hukum secara adil sesuai yang terdapat dalam surat an-Nisa ayat 58, hakim dapat menggali hukum yang hidup dalam masyarakat dengan menggunakan perlindungan hukum dalam perspektif peraturan perlindungan konsumen sesuai dengan peraturan perundang-undangan yang sudah ada agar

37 Jaih Mubarok dan Hasanudin, Prinsip-Prinsip Perjanjian, Cet.I, (Bandung: Remaja Rosdakarya), hlm.155.

${ }^{38} \mathrm{R}$ Soeroso, Hukum Acara Perdata Lengkap \& Praktis HIR, Dan Yurisprudensi (Sinar Grafika, 2010), hlm.135. 
terciptanya rasa keadilan sesuai yang diungkapkan dalam teori keadilan oleh Hans Kelsen, hakim dapat memutus agar menciptakan kondisi yang memuaskan supaya semua orang merasa bahagia terhadap putusan yang bersifat substansial dalam ekonomi syariah dengan prinsip keseimbangan antara kepentingan pihak nasabah dengan menggunakan kewenangan ex-officionya dalam melihat kembali permasalahan yang ada.

\section{PENUTUP}

\section{A. KESIMPULAN}

Prosedur Eksekusi Hak Tanggungan Akad Musyarakah yang dilakukan secara parate eksekusi maka hal tersebut tidak ideal untuk tercapainya kepastian hukum karena tidak sesuai dengan Undang-Undang Nomor 4 Tahun 1996 Tentang Hak Tanggungan atas Tanah Beserta Benda-benda yang Berkaitan dengan Tanah Penjelasan Umum Angka 9 dan Buku Standar Operasional Musyarakah OJK, "BUS/UUS/BPRS tidak diperkenankan melakukan eksekusi langsung. Seharusnya pihak bank mengajukan permohonan eksekusi terlebih dahulu kepada Pengadilan Agama dan selanjutnya pengadilan agama menindak lanjutinya selayaknya eksekusi putusan yang telah berkekuatan hukum tetap.

Bentuk perlindungan nasabah terdapat berdasarkan asas-asas dalam Undang-Undang Nomor 8 Tahun 1999 Tentang Perlindungan Konsumen, berasaskan manfaat, keadilan, keseimbangan, keamanan dan keselamatan serta kepastian hukum, nasabah berhak mendapatkan transparansi kecukupan jaminan, total hutang dan biaya ganti rugi dengan prinsip transparansi sesuai Pasal 2 Peraturan Otoritas Jasa Keuangan Nomor: 1/POJK.07/2013 Tentang Perlindungan Konsumen Sektor Jasa Keuangan.

\section{B. SARAN}

Karena persoalan eksekusi hak tanggungan akad musyarakah menjadi problem utama oleh karena itu agar pihak lembaga dalam menyalurkan pembiayaan dengan akad Musyarakah menerapkan prinsip kehati-hatian untuk menghindari nasabah (shahibulmaal) cedera janji terkait transparansi informasi, 
menerapkan asas-asas perjanjian dan prinsip profit and lost sharing dan hakim menggali perkara ekonomi syariah demi tercapainya keadilan menggunakan Pasal 178 ayat 1 HIR menyatakan bahwa hakim secara ex officio wajib mencakupkan segala alasan hukum yang tidak dikemukakan para pihak yang berperkara untuk bahan masukan dalam penyusunan dan pembentukan Surat Edaran Mahkamah Agung yang mengatur tentang penyelesaian sengketa ekonomi syariah dalam eksekusi haktanggungan pada Perbankan Syariah khususnya dapat lebih maksimal dilaksanakan terkait kepastian hukum pelaksanaan eksekusi, penetapan jumlah penjualan jaminan dan total sisa hutang. 


\section{DAFTAR PUSTAKA}

Ali, Achmad, Menguak Teori Hukum (Legal Theory) \& Teori Peradilan (Judicial prudence) Termasuk Undang-Undang (Legisprudence), vol. I, Jakarta: Kencana Prenada Media Group, 2010.

A. Yovita Mangesti dan Bernard L. Tanya, Moralitas Hukum, Yogyakarta: Genta Publishing. 2014.

Aburaera, Sukarno dan Muhadar, Filsafat Hukum: Teori dan Praktek, Jakarta: Kencana, 2017.

Ata Ujan, Andre, Filsafat Hukum, Membangun Hukum, Membela Keadilan, Yogyakarta: Kanisius, 2009.

Anam, Zuhrul, Prosedur Eksekusi Putusan Basyarnas, Hak Tanggungan dan Putusan Pengadilan Agama yang Simetris, dikutip dari http:badilagmahkamahagung.co.id

Capra, M. Umer, Islam and the economic Challege,Leicester: The Islamic Foundation, 1994), terj. Ikhwan Abidin Basri, Islam dan Tantangan Ekonomi, Depok: Gema Insani: 2000.

Demesky, Yordan, Tesis: PelaksanaanParate Eksekusi Hak Tanggungan sebagai Alternatif Penyelesaian Kredit Bermasalah di PT Bank Permata Tbk, Jakarta: Universitas Indonesia.

Harahap, M. Yahya, Ruang Lingkup Permasalahan Eksekusi Bidang Perdata, Jakarta: Sinar Grafika, 2005.

Fitri, Al, Perlukah Sita Eksekusi Terhadap Objek Hak Tanggungan, Hakim Madya Pratama Pengadilan Agama Blamabangan Umpu. Dikutip dari http:badilagmahkamahagung.co.id

HS, Salim, Perkembangan Teori Dalam Ilmu Hukum, (Jakarta: Rajagrafindo Persada, 2010.

Huijebers, Theo, Filsafat Hukum Dalam Lintasan Sejarah, Yogyakarta: Kanisius, 1982. 
Idri, Hadis Ekonomi,Ekonomi dalam Perspektif Hadis Nabi, Jakarta: Kencana, 2015.

Irianto, Sulistyowati dan Shidarta, Metode Penelitian Hukum: Konstelasi dan Refleksi, (Jakarta: Yayasan Pustaka Obor Indonesia, 2009.

Jajuli, Sulaeman, Ekonomi Islam Umar bin Khattab, Yogyakarta: Deepublish, 2016.

L Tanya, Bernard dkk, Teori Hukum: Strategi Tertib Manusia Lintas Ruang dan Generasi, Genta Yogyakarta: Publising, 2013.

Mahmud Marzuki, Peter, Pengantar Ilmu Hukum, Jakarta: Kencana Prenada Media Group, 2008.

Maksum, Muhammad, Penerapan Hukum Jaminan Fidusia Dalam Kontrak Pembiayaan Syariah, Jurnal Cita Hukum, FSH UIN Syarif Hidayatullah Jakarta Vol.3 No.1, 2015.

Mubarok, Jaih dan Hasanudin, Prinsip-Prinsip Perjanjian, Cet.I, Bandung: Remaja Rosdakarya.

Munir, Abdul, Akta Pemberian Hak Tanggungan dalam Pembiayaan Musyarakah pada Perbankan Syariah Menurut Hukum Islam, Tesis, Universitas Sebelas Maret, 2015.

Radhbruch, Gustav, Rechtsphilosophie, Stuttgart: K.F Koehler Verlag, 1973.

Salam, Abd. Eksekusi Hak Tanggungan dalam Akad Murabahah atas Alasan Wanprestasi (Perspektif Perlindungan Nasabah), Dikutip dari www.badilagmahkamahagung.go.id

Salam Siku, Abdul, Perlindungan Hak Asasi Saksi dan Korban dalam Proses Peradilan Pidana, Indonesia Prime, 2016.

Salim dan Erlies Septiana Nurbani, Penerapan Teori Hukum Pada Penelitian Disertasi dan Tesis, Depok: Rajagrafindo Persada, 2014. 
Sagama, Suwardi, Analisis Konsep Keadilan, Kepastian Hukum dan Kemanfaatan dalam Pengelolaan Lingkungan, Mazahib, Jurnal vol. xv, No. 1, IAIN, 2016.

Supianto, Hukum Jaminan Fidusia, Prinsip Publisitas Pada Jaminan Fidusia, Garudhawaca, 2015

Soebekti, R. Hukum Acara Perdata), Bandung: Bina Cipta, 1989.

Soeroso, R, Hukum Acara Perdata Lengkap \& Praktis HIR, Dan Yurisprudensi (Sinar Grafika, 2010.

Suadi, Amran, Penyelesaian Sengketa Ekonomi Syariah, Jakarta: Kencana, 2018.

S. Pradja, Juhaya, Ekonomi Syariah, (Bandung: Pustaka Setia, 2012.

Zulfa Nailufar, Eva, Disertasi:Studi Kritis UMP DKI dalam Perspektif Sistem Pengupahan Berkeadilan Menurut Islam, (Jakarta: UIN Syarif Hidayatullah, 2014. 